where it uncovered some of the richest fossil fields in the world. Dr. Andrews was awarded the Elisha Kent Kane Gold Medal of the Philadelphia Geo. graphical Society, previously given to only eight explorers. Brown University and Beloit College have both conferred on him the degree of honorary doctor of science. $\mathrm{He}$ has been given the Hubbard Medal of the National Geographic Society in recognition of his discoveries in Asia. He is well known as a lecturer and author of popular books and articles on the results of his various expeditions, including a large volume covering his entire field work in Mongolia and China up to the present time entitled "The New Conquest of Central Asia".

\section{Organisation of Museums}

THE Madrid Conference on Museography on October 28-November 1, 1934, attended by seventyfive experts representing twenty different countries, was noteworthy for the publicity it gave to the organic life led by museums outside their actual exhibition galleries, quite as much as for the success of the Conference in paving the way for a general treatise on the principles and practice of museums. The main object of this Conference, organised by the International Museums Office and the International Institute of Intellectual Co-operation, was to collect observations and the results of actual experience from as large a number of museums and countries as possible, rather than the formulation of general rules. The agenda of the Conference included discussions on the general principles of the architecture of a museum, on museum equipment both in exhibition and other public rooms and in the museum services; on lighting, heating, ventilation and air-conditioning; the conversion of ancient monuments and other buildings into museums ; general principles regarding the enhancement of works of art; methods of presenting collections; organisation of stores, reserves and study collections; permanent and temporary exhibitions; problems arising from the growth of collections; exhibition material; plans of rooms and the numbering and labelling of exhibits. A number of special questions such as collections of sculpture, decorative and industrial art, folk-art and ethnography, and graphic and numismatic collections were also discussed. The Academy of Fine Arts, Madrid, was specially fitted up for the Conference by the Spanish Government, and the International Museums Office lent a considerable amount of graphic and photographic documents to illustrate the papers.

\section{Electric Discharge Lamps for Road Lighting}

Is many of the long stretches of main roads between towns and villages the only practical way of lighting at present seems to be by means of the lamps on the vehicles. In a paper on "Electric Discharge Lamps and Road Lighting" read to the Institution of Automobile Engineers on December 11, Mr. H. Warren and Mr. L. J. Davies show how the length of the permanent illumination of roads can be extended, with acceptable economy, by means of the new discharge lamps, when care is taken to distribute the light scientifically by means of suitable lanterns. Controlling the reflective properties of the road surfaces has also to be taken into consideration. With mereury and sodium vapours we have two substances which, when excited in the correct way, produce a sufficient proportion of energy in the visible spectrum to give a two- or three-fold increase in efficiency over incandescent lamps. A fifty-fold efficiency is theoretically possible, but the practical utilisation of electrical discharges has just made a beginning. At present, electric discharge lamps for street lighting are of two main types, highpressure mercury vapour and sodium vapour. The former type of lamp is most favoured in Great Britain, while on the Continent and in America the sodium vapour lamp is most used. Mercury discharge lamps have an excellent 'luminous output' during their lives, which are longer than those of other forms of lamp. The colour of the lamp, when viewed directly, is greenish-white. In the colours radiated, blue, green and yellow predominate, but red is practically lacking. By incorporating cadmium with the mercury a satisfactory red tinge can be introduced, but at a slightly lower efficiency. The colour correction of these lamps is receiving a great deal of attention in commercial research laboratories at present.

\section{Continuously Evacuated Radio Transmitting Valves}

AT the meeting of the Wireless Section of the Institution of Electrical Engineers on February 6, a paper entitled "Continuously Evacuated Valves and their Associated Equipment" was read by Mr. C. R. Burch and Dr. C. Sykes. This paper deseribes the development of demountable thermionic transmitting valves of various power ratings, the valves being evacuated continuously by means of oil condensation pumps. This work has arisen out of some experiments carried out in 1929 on the distillation of lubricating oil in a molecular still. It was found that one of the fractions was about a thousand times less volatile than mercury, so that if such a liquid could be used as the working fluid in a condensation pump, a vacuum of the order of $10^{-6} \mathrm{~mm}$. should be attainable without the use of liquid air or other refrigerants; and such a vacuum is quite adequate for valve exhaustion. These expectations have been fully realised in the development of oilcondensation pumps which will work against a forevacuum of $0.05 \mathrm{~mm}$. and will produce a vacuum of $10^{-3}-10^{-6} \mathrm{~mm}$. at a speed of 20 litres per second. Such pumping equipment is described in the paper in some detail, and reference is made to its application to the production of thermionic valves of a power rating ranging from $20 \mathrm{kw}$. to $500 \mathrm{kw}$. for highfrequency furnaces and for radio transmitting stations. Several valves of the $30 \mathrm{kw}$. order have been in use on commercial radio traffic at the Post Office station at Rugby for long periods, and they have given satisfactory service. A $500 \mathrm{kw}$. valve is in the stage of experimental trial on the long-wave transmitter at Rugby. The relative merits of these valves and those of the sealed-off type were discussed 
briefly in the paper, and were enlarged upon by several speakers in the discussion which followed the reading of the paper.

\section{Deep-Sea Observations with the Bathysphere}

Foun years ago, Dr. William Beebe and Mr. Otis Barton descended in their 'bathysphere'- - a steel ball fitted with quartz windows - to a depth of a quarter of a mile below the surface of the ocean off Bermuda. During the season of 1934 they successfully established a new depth record of $3,028 \mathrm{ft}$. In the $\mathrm{National}$ Geographic Magazine of December 1934 and the Bulletin of the New York Zoological Society of November-December 1934, interesting articles deal with the fitting-out, operation and scientific observations made, during these latest dives. Excellent photographs in the text provide a word picture of the undertaking, and a series of coloured plates give vivid impressions of the strange and bizarre forms of life as seen by Dr. Beebe through the windows of the ball and described over the telephone line between the bathysphere below and the parent ship at the surface. Three deep-sea fish, new to science, are described, including the five-lined constellation fish, Bathysidus pentagrammus, which Dr. Beebe speaks of as one of the most gorgeous deep-sea inhabitants he has ever seen. Five rows of photophores emitting yellow and purple light produced a beautiful pattern of illumination through the darkness. From this and other records, there can be little doubt as to the success and scientific value of this daring method of observa

\section{Optical Research}

Ar the meetings of the Institut d'Optique, held periodically at the Sorbonne and generally under the chairmanship of Prof. Charles Fabry, director of the Institut, the communications considered relate as a rule to one particular branch of the subject, and the Revue d'Optique Theorique et Instrumentale issues a separate copy of the proceedings which may run to as much as 50 pages. Last year, the January meeting dealt with the employment of liquid prisms in spectrographs, that of March with interference methods of studying movements of the air, the April meeting with ultra-violet polarimetry and with the densities of photographic images, and the June meeting with the light of the night sky. In several cases the subject is introduced by a short sketch of past work on it and its present aims and problems, given by the president, and descriptions of current methods and instruments by specialists in the subject follow. These pamphlets seem capable of affording great assistance to those requiring brief résumés of the present positions of the various branches of optical research.

\section{Systematics of the Diptera}

Mr. P. H. Grimshaw has recently published a useful article entitled "Introduction to the Study of Diptera, with a Key for the Identification of Families" (Proc. Roy. Phys, Soc., Edin., 22, Pt. 4, July 1934). The paper gives a clear account, accompanied by illustrations, of the various structural features of importance in classification. A list of the chief general works on the order is provided and a diagnostic key to all the existing families. The key is translated and adapted from Lindner's "Fliegen der palaeartischen Region" and should prove especially valuable to those entomologists who are not specialists in the insect order concerned.

\section{Review of Seismology}

THE National Research Council of the National Academy of Sciences at Washington is issuing a series of bulletins on the physies of the earth, to give scientific workers who are not specialists in the subjects treated an idea of the position and problems of various branches of geophysics. Among the bulletins in this series which have already been issued are those on volcanology, the figure of the earth, meteorology, the age of the earth and oceanography. Recently, Bulletin No. 90 on seismology has appeared. It has been prepared by a Committee of which Prof. J. B. Macelwane is chairman. Within 219 pages it includes twenty chapters, and gives a very valuable and interesting general view of the subject. Chapters by the chairman include-the definition and classification of earthquakes, tectonic earthquakes, plutonic earthquakes, rock fall earthquakes, body waves, reflection and refraction of seismic waves, surface waves and paths and velocities of seismic waves within the earth; H. O. Woods contributes articles on volcanic earthquakes, field investigation and surface geology in relation to the 'apparent' intensity ; articles by H. F. Reid deal with magnetic effects, earthquake mechanics and with the focus. The principle of the seismograph is described by J.A. Anderson, and P. Byerly contributes five articles on analysis of seismograms in earthquakes, records at intermediate and great distances, time distance curves, reduction of trace amplitude, and seismic geography. The Bulletin has numerous bibliographies and is priced at 2 dollar

\section{Books on Anthropology and Archazology}

Catalogue No. 574 (Anthropology and FolkloreArchæologyand Ethnography)issued by Messrs. Francis Edwards, Ltd., 83 High Street, Marylebone, London, W.1, including both new and second-hand books, though, naturally, the latter predominate, contains just under a thousand items. On looking through the list, two points occur, one being the high average in the quality of the books from the point of view of the anthropologist, and secondly the fact that, with certain exceptions, the prices do not rule high. With regard to the first point, the subjects covered by the catalogue, it is almost needless to say, have been a happy hunting ground for the wilder theorist and speculation has been rife in their literature. It is evident that here on the whole a wide discretion has been exercised in selection. The question of price is no less interesting. It is not intended to convey that this catalogue is an exceptional opportunity for bargain hunters-although it would be possible to form from its pages an excellent nucleus of a reference 